УДК 342.56

DOI https://doi.org/10.32844/2618-1258.2019.3-1.39

ЗИРІН Б.О.

\title{
ПОНЯТТЯ Й ОСНОВНІ ЕЛЕМЕНТИ ФІЗКУЛЬТУРНО-ОЗДОРОВЧОЇ ДІЯЛЬНОСТІ
}

У статті досліджується поняття «фізкультурно-оздоровча діяльність», аналізуються його основні елементи, такі як сфери діяльності, суб'єкти діяльності, мета діяльності, заходи й послуги. Автор доходить висновку, що суб'єктів фізкультурно-оздоровчої діяльності можна класифікувати залежно від сфери їхньої діяльності, а саме на осіб: а) які створюють умови для фізкультурно-оздоровчої діяльності; б) для яких створюють умови; в) хто надає послуги. 3'ясовано, що фізкультурно-оздоровча діяльність спрямовується в таких основних сферах: в освітній; за місцем проживання та відпочинку громадян; за місцем роботи. Фізкультурно-оздоровча діяльність упроваджується в навчально-виховну сферу, але разом із фізичним вихованням дітей і молоді з урахуванням їхнього стану здоров'я, рівня психічного та фізичного розвитку. Визначено, що держава на законодавчому рівні встановила сфери свого впливу для врегулювання й упровадження фізкультурно-оздоровчої діяльності серед різних верств населення з метою реалізації права громадян на зайняття фізичною культурою і спортом незалежно від соціального й майнового стану, походження, віросповідання, расової та національної належності, статі, освіти, роду й характеру занять, місця проживання та інших обставин. Установлено, що фізкультурно-оздоровчі заходи - це заходи, що здійснюються суб'єктами фізкультурно-оздоровчої та спортивної діяльності для залучення різних груп населення до занять фізичною активністю (фізичною культурою і спортом) з метою покращення здоров'я або досягнення певного спортивного результату й/або пропагування здорового способу життя. Зроблено висновок, що держава та інші суб'єкти, що створюють умови для фізкультурно-оздоровчої діяльності, здійснюють адміністративно-правове регулювання зі спеціальною метою - 3 метою покращення здатності людини ефективно працювати, насолоджуватися вільним часом, бути здоровим, чинити опір гіпокінетичним хворобам і протистояти надзвичайним ситуаціям.

Ключові слова: фізкультурно-оздоровча діяльність, суб'єкти, сфера діяльності, заходи, послуги.

The article explores the concept of "fitness activities" analyzes its basic elements such as areas of activity, subjects of activity, purpose of activity, means and services. The author concludes that the subjects of sports and fitness activities can be classified depending on the scope of their activities, namely, individuals: a) create conditions for sports and fitness activities; b) for which they create conditions; c) who provides the services. It is found out that physical and health activity is directed in the following main areas: in the educational; at the place of residence and rest of citizens; at the place of work. Physical and health activities are implemented in the educational sphere, but together with the physical education of children and young people, taking into account their health status, level of mental and physical development. It is determined that the state at the legislative level has established the spheres of its influence to regulate and introduce physical activity among different segments of the population in order to realize the right of citizens to engage in physical culture and sports regardless of social and property status, origin, religion, race, nationality gender, education, type and nature of occupation, place of residence and other circumstances. It is established that physical and health measures are measures carried out by subjects of physical and health and sports activity in order to involve different groups of people in physical activity (physical culture and sports) for the purpose of improving health or achieving a certain sports result and/or

(C) ЗИРІН Б.О. - слухач аспірантури (Міжрегіональна Академія управління персоналом) 
promoting a healthy lifestyle. It is concluded that the state and other entities that create conditions for physical and fitness activities carry out administrative and legal regulation with a specific purpose - in order to improve the person's ability to work effectively, enjoy free time, be healthy, resist hypokinetic diseases and resist extraordinary diseases situations.

Key words: fitness and fitness activities, subjects, field of activity, events, services.

Вступ. Фізкультурно-оздоровча діяльність $є$ важливим засобом підвищення соціальної і трудової активності людей, задоволення їхніх моральних, естетичних і творчих запитів, життєво важливої потреби взаємного спілкування, для розвитку дружніх стосунків між народами і зміцнення миру. Сама мета гармонійного (всебічного) розвитку особистості $\epsilon$ продуктом історії розвитку людства. Але умови для ії реалізації особистість одержує лише на певному етапі історичного розвитку. Усебічний розвиток людині необхідний для того, щоб мати можливість брати участь у всіх напрямах діяльності (професійній, громадській, спортивній, художній тощо). Для цього потрібно розвинути структуру особистості, зробити іiї комунікативною, здатною до перетворювальної художньої діяльності, сформувати ціннісні орієнтації. Це можливо за умови різноманітності змісту, форм і способів діяльності людини та їх оптимального поєднання в процесі іiі культурного розвитку [1].

Постановка завдання. Мета статті полягає в тому, щоб на основі теорії права, теорії адміністративного права, думок учених-правників щодо цієї проблематики й чинного законодавства з'ясувати зміст і сформувати поняття та основні елементи фізкультурно-оздоровчої діяльності.

Результати дослідження. Фізкультурно-оздоровча діяльність - це сукупність заходів і послуг, які врегульовані адміністративно-правовими прочедурами, щзо поєднують у собі публічноправові інтереси суб 'єктів сфери фізичної культури і спорту, які проводяться/надаються з метою покращення здатності людини ефективно працювати, насолоджуватися вільним часом, бути здоровим, чинити опір гіпокінетичним хворобам і протистояти надзвичайним ситуачіям.

Виходячи з визначення, виокреммо основні структурні елементи поняття «фізкультурно-оздоровча діяльність». Воно складається з таких елементів: а) сфери діяльності; б) суб'єктів діяльності; в) мети діяльності; г) заходів; д) послуг.

Спочатку коротко проаналізуємо сфери фізкультурно-оздоровчої діяльності. Сфера діяльності - це галузь фізичного або духовного життя, діяльності людини чи суспільства; галузь знання, виробництва, мистецтва тощо [2, с. 1220]. Тенденції мобільності й динамічності розвитку суспільства, суспільних відносин, права та законодавства загалом стосуються всіх без винятку світових держав, у т. ч. й України, для якої відправною точкою бурхливого розвитку різних сфер суспільної життедіяльності можна справедливо вважати здобуття та проголошення ії незалежності. Указане пов'язується з істотною й різнобічною зміною ідеології світогляду людини, що створило передумови для перегляду вже наявних і розроблення й упровадження нових теорій, концепцій і підходів у всіх сферах людського буття, у т. ч. тих, що стосуються концептуальної зміни акцентів у правовій системі нашої держави [3].

У Законі України «Про фізичну культуру і спорт» у другому розділі розкриваються сфери, які сьогодні $\epsilon$ найбільш важливі для держави. Держава в особі уповноважених нею органів публічного адміністрування створює необхідні умови для підготовки наукових і викладацьких кадрів, розвитку наукових досліджень у галузі фізичної культури і стимулює впровадження їх у суспільну практику [4].

Відповідно до вказаного Закону, фізкультурно-оздоровча діяльність спрямовується в таких основних сферах: а) в освітній; б) за місцем проживання та відпочинку громадян; в) за місцем роботи. Фізкультурно-оздоровча діяльність упроваджується в навчально-виховну сферу, але разом із фізичним вихованням дітей і молоді, ураховуючи при цьому їхній стан здоров'я, рівень психічного та фізичного розвитку.

Крім того, зазначена діяльність здійснюється стосовно таких категорій осіб: а) військовослужбовців (Збройних сил України, органів внутрішніх справ, інших військових формувань); б) з інвалідністю; в) які перебувають у місцях попереднього ув'язнення й в установах виконання покарань; г) сільського населення.

Отже, держава на законодавчому рівні встановила сфери свого впливу для врегулювання та впровадження фізкультурно-оздоровчої діяльності серед різних верств населення з метою реалізації права громадян на зайняття фізичною культурою і спортом незалежно від соціального й 
майнового стану, походження, віросповідання, расової та національної належності, статі, освіти, роду й характеру занять, місця проживання та інших обставин

Більш детально особливості адміністративно-правового регулювання вищезазначених сфер фізкультурно-оздоровчої діяльності будуть розкрито у наступному розділі нашого дослідження.

Наступний елемент фізкультурно-оздоровчої діяльності - ие особи, які організовують, беруть участь, контролюють зазначену діяльність, тобто суб 'єкти. Суб'єкти сфери фізичної культури і спорту - фізичні або юридичні особи, які здійснюють свою діяльність з метою розвитку фізичної культури і спорту. Суб'єктами сфери фізичної культури і спорту є фізичні особи, які займаються фізичною культурою і спортом, у тому числі спортсмени; фахівці сфери фізичної культури і спорту; заклади фізичної культури і спорту; відповідні органи влади [4]. Як ми вже зазначали вище, у Закон України «Про фізичну культуру і спорт» необхідно внести зміни щодо визначення терміна «суб'єкти сфери фізичної культури і спорту» й викласти його в такій редакції: «суб'єкти фізкультурно-оздоровчої та спортивної діяльності - це фізичні або юридичні особи, які здійснюють свою діяльність з метою покращення здатності людини ефективно працювати, насолоджуватися вільним часом, бути здоровим, чинити опір гіпокінетичним хворобам і протистояти надзвичайним ситуаціям. Суб 'єктами сфери фізкультурно-оздоровчої та спортивної діяльності є особи, які займаються або надають послуги з оздоровлення, фізичної активності, у тому числі спортсмени; фахівиі сфери фізичної культури і спорту; заклади фізичної культури $i$ спорту; відповідні органи публічного адміністрування.

Суб'єктів фізкультурно-оздоровчої діяльності можна класифікувати залежно від сфери їхньої діяльності, а саме на такі: а) які створюють умови для фізкультурно-оздоровчої діяльності; б) для яких створюють умови; в) хто надає послуги.

У свою чергу, група суб'єктів, які створюють умови для фізкультурно-оздоровчої діяльності, поділяється на: а) державу; б) органи публічного адміністрування; в) громадські організації (громадські організації фізкультурно-спортивної спрямованості; організації осіб з інвалідністю тощо); г) власники підприємств, установ, організацій.

Група суб'єктів, для яких створюють умови для заняття фізкультурно-оздоровчою діяльністю, поділяється на: а) населення країни; б) працівників і членів їхніх сімей; в) дітей і молодь; г) учнів і студентів; д) військовослужбовців; е) осіб з інвалідністю; є) громадян, які перебувають у місцях попереднього ув'язнення й в установах виконання покарань; ж) сільське населення тощо.

Група суб'єктів фізкультурно-оздоровчої діяльності, що надає послуги: а) педагогічні колективи; б) фахівці фізичного виховання; в) власники фізкультурно-оздоровчих і спортивних споруд, спеціальних приміщень для занять фізкультурою і спортом і фізкультурно-оздоровчого і спортивного інвентарю або уповноважені ними органи; г) адміністрація фізкультурно-оздоровчих і спортивних споруд; д) організатор спортивного заходу або занять фізичною культурою тощо.

Наступний елемент - ие фізкультурно-оздоровчі заходи.

Фізкультурно-оздоровчі заходи - заходи, що здійснюються організаторами фізкультурно-оздоровчих заходів для залучення різних груп населення до занять фізичною культурою [4]. Загальна мета фізкультурно-оздоровчих заходів полягає в тому, щоб покращити здоров'я, оптимізувати фізичний розвиток населення. Ці заходи також спрямовані на створення певного життєвого тонусу та зниження стомлення від розумової роботи.

Різні види заходів регламентуються різними нормативно-правовими актами. Наприклад, якщо фізкультурно-оздоровчі заходи проводяться власниками для своїх працівників і членів їхніх сімей, то порядок створення й використання матеріальної бази для занять фізичною культурою, фінансування, забезпечення спеціалістами для індивідуальних і колективних занять визначаються законодавчими, іншими нормативними актами та колективними договорами [4]. Якщо зазначені заходи проводяться у вищих навчальних закладах, то вони здійснюється на підставі вимог державного стандарту, галузевих стандартів і стандартів вищої освіти вищих навчальних закладів, затверджених у встановленому законодавством порядку [5], тощо.

Спортивне змагання за своєю сутністю є одним із різновидів спортивного заходу, а за своєю формою є зовнішнім вираженням реалізації суб'єктами фізкультурно-оздоровчої та спортивної діяльності своєї спортивної правосуб'єктності й водночас формою спортивної діяльності взагалі. Аналіз сутності цього поняття наводить на думку, що спортивне змагання є складною за змістом і сутністю категорією, що включає в себе комплекс юридичних, економічних і соціальних елементів. А.М. Апаров дає таке визначення цього поняття: спортивне змагання - це система створюваних організатором відповідного спортивного заходу правових, економічних та організа- 
ційних заходів, спрямованих на ефективну, точну й повну реалізацію затвердженого регламенту (положення) змагання та забезпечення умов його проведення з урахуванням дотримання прав та інтересів учасників змагання, його організаторів, глядачів та інших осіб (у т. ч. заходи, що є необхідними для забезпечення нормального ходу змагання й забезпечення їх виконання), що виявляються в суперництві, змаганні, боротьбі спортсменів за певні блага з метою досягнення завдяки власним досягненням переваг перед іншими спортсменами, тобто з метою досягнення певного спортивного результату, кращого від спортивного результату інших спортсменів [3, с. 14].

Отже, фізкультурно-оздоровчі заходи - ие заходи, щя здійснюються суб' єктами фізкультурно-оздоровчої та спортивної діяльності для залучення різних груп населення до занять фiзичною активністю (фізичною культурою і спортом) з метою покращення здоров'я або досягнення певного спортивного результату й/або пропагування здорового способу життя.

Фізкультурно-оздоровчі послуги охоплюють фізичну активність; здавання спортивних споруд в оренду; консультаційні послуги. Пропонування послуг, пов'язаних із фізичною активністю, включає в себе розроблення, розвиток і впровадження фізкультурно-оздоровчих програм. Причому в одному випадку клуб, центр може сам вибирати вид фізичної активності, а в іншому клієнти диктують, що конкретно вони хочуть. Вид фізичної активності, спортивно-оздоровча програма багато в чому залежать від типу клубу. Вони бувають громадськими й комерційними. Перші отримують фінансування на національному, регіональному та муніципальному рівнях. Другі фінансуються приватним капіталом, і їхня діяльність залежить від власника клубу [6].

Забезпечення необхідними спортивними спорудами є другим видом фізкультурно-оздоровчих послуг. Часто спортивні споруди орендують, тоді вони стають видом послуг. Сфера консультаційних послуг. Консультанти працюють і на спортивних спорудах, і в оздоровчих центрах. Вони допомагають клієнтам у виборі необхідного для них залежно від віку й рівня фізичної підготовленості типу оздоровчої програми, визначити інтенсивність занять, навчають азів самоконтролю тощо [6].

Визначення основних тенденцій розвитку ринку фізкультурно-оздоровчих послуг вимагає уточнення трактувань основних складників цієї категорії. Так, основні спортивно-оздоровчі послуги - це такі, за яких людина залежно від мети, що переслідується (оздоровлення, відпочинок, реабілітація, фізична досконалість), безпосередньо залучена в процес занять фізичною активністю [7]. Супутні фізкультурно-оздоровчі послуги - послуги, які являють собою створення можливостей (тимчасового комфорту) для людини в її заняттях фізичною активністю, у ії активному відпочинку. Наприклад, надання зручного обслуговування протягом усього періоду відвідування спортивних споруд, послуги тимчасового зберігання особистих речей людини (гардероб, роздягальня, камера зберігання) тощо [8].

Сервісні фізкультурно-оздоровчі послуги - це послуги, за яких під час безпосереднього процесу їх надання участь людини менш активна (під час масажу - пасивна) або які проходять без іiї участі. Наприклад, послуги зі складання індивідуальної програми занять, консультування 3 питань фізичного та психологічного стану людини, що займається, тощо. Спортивна послуга $\epsilon$ складником фізкультурно-оздоровчих послуг тільки тоді, коли вона безпосередньо пов'язана 3 руховою активністю людини. Розрізняють спортивну послугу «для себе» - послугу, що задовольняє фізкультурно-оздоровчі потреби людини в їі індивідуальній або командній руховій активності в змаганнях; спортивну послугу «для вищих досягнень» - послугу, що задовольняє масову потребу глядачів у спостеріганні за спортивно-видовищним процесом (дією, заходом) [7].

У Європі «культ здоров'я» давно має підтримку держави та відповідне фінансування. В Україні сфера фізкультурно-оздоровчої діяльності також стрімко розвивається, але до «європейського рівня» нам ще далеко. Труднощі, з якими стикаються у сфері надання фізкультурно-оздоровчих послуг:

- недосконалість системи управління й недостатній рівень державної підтримки галузі;

- відсутність національних стандартів якості фізкультурно-оздоровчих і спортивних послуг і системи їх добровільної сертифікації;

- відсутність атестації та загальнодержавної сертифікації фізкультурно-оздоровчих закладів незалежно від форми власності й відомчої належності;

- різке зростання цін на послуги;

- диспропорції в доступності на послуги різним групам населення країни;

- не сформований в Україні «культ здоров'я» [9].

Отже, фізкультурно-оздоровча послуга - ие діяльність із надання матеріальних чи нематеріальних благ споживачеві для задоволення його потреб у фізичній активності (фізичній культурі і спорті) з метою покращення здоров'я і пропагування здорового способу життя. 
Висновки. Отже, держава та інші суб'єкти, що створюють умови для фізкультурно-оздоровчої діяльності, здійснюють адміністративно-правове регулювання зі спеціальною метою - 3 метою покращення здатності людини ефективно працювати, насолоджуватися вільним часом, бути здоровим, чинити опір гіпокінетичним хворобам і протистояти надзвичайним ситуаціям.

\section{Список використаних джерел:}

1.Мартинюк О.В. Фізкультура і спорт у сучасному суспільстві. 2019. URL: https://vseosvita.ua/library/fizicna-kultura-i-sport-u-sucasnomu-suspilstvi-117729.html.

2.Великий тлумачний словник сучасної української мови / укл. В.Т. Бусел. Київ ; Ірпінь : ВТФ «Перун», 2001. 1440 c.

3.Апаров А.М. Концепція спортивного права: огляд ключових аспектів. Вісник ОНУ ім. I.І. Мечникова. Серія «Правознавство». 2017. Т. 22. Вип. 1 (30). С. 6-19.

4.Про фізичну культуру і спорт : Закон України від 24.12.1993 № 3808-XII. URL: https://zakon.rada.gov.ua/laws/card/3808-12.

5.Про затвердження Положення про організацію фізичного виховання і масового спорту у вищих навчальних закладах : Наказ Міністерства науки і освіти України від 11.01.2006 № 4. URL: https://zakon.rada.gov.ua/laws/show/z0249-06/ed20060321/find?text=\%D0\%F3\%F5\%EE\%E2 $\% \mathrm{E} 0+\% 28 \% \mathrm{~F} 4 \% \mathrm{~B} 3 \% \mathrm{E} 7 \% \mathrm{E} 8 \% \mathrm{~F} 7 \% \mathrm{ED} \% \mathrm{E} 0 \% 29+\% \mathrm{E} 0 \% \mathrm{EA} \% \mathrm{~F} 2 \% \mathrm{E} 8 \% \mathrm{E} 2 \% \mathrm{ED} \% \mathrm{~B} 3 \% \mathrm{~F} 1 \% \mathrm{~F} 2 \% \mathrm{FC}$.

6.Марчук В., Марчук О. Особливості маркетингу фізкультурно-оздоровчих послуг. Фізичне виховання, спорт і культура здоров'я у сучасному суспільстві : збірник наукових праць. 2009. № 3. С. 16-18.

7.Черданцева І.Г., Ібрагімова Л.С., Ібрагімов Е.Ю. Теоретичні аспекти реалізації маркетингової конценції на ринку спортивно-оздоровчих послуг. Збірник наукових праць ЧДТУ. Серія «Економічні науки». 2018. Вип. 49. С. 59-67.

8.Ищенко А.А., Мищенко И.А. Проектный менеджмент в организации деятельности предприятий, оказывающих спортивно-оздоровительные услуги населению. Модели управления в рыночной экономике : сборник научых трудов / общ. ред. Ю.Г. Лысенко ; Донецкий нац. ун-т. Донецк : ДонНУ, 2002. Спец. выпуск. С. 334-340.

9.Саранчук О.В., Діброва Т.Г. Особливості просування спортивних послуг на споживчому ринку. URL: http://pidruchniki.com/12720712/menedzhment/osoblivosti_poslugi_spetsifichno go_ vidu_tovaru. 